\title{
MUTIARA HOME CARE
}

\author{
Janno Sinaga ${ }^{*}$, Amila1, Evarina Sembiring ${ }^{2}$ \\ ${ }^{1}$ Program Studi Ilmu Keperawatan, Universitas Sari Mutiara Indonesia, Medan, Indonesia \\ ${ }^{2}$ Program Studi Kesehatan Masyarakat, Universitas Sari Mutiara Indonesia, Medan, Indonesia \\ *Penulis Korespodensi : mila_difa@yahoo.co.id
}

\begin{abstract}
Abstrak
Tujuan jangka panjang pelaksanaan program Mutiara Home Care adalah menciptakan akses bagi terciptanya wirausaha baru, menunjang otonomi kampus perguruan tinggi melalui perolehan pendapatan mandiri. Bagi pasien program ini membantu meringankan biaya rawat inap yang makin mahal, karena mengurangi biaya akomodasi pasien, transportasi dan konsumsi keluarga. Dampak ekonomi nasional home care bagi pasien dan keluarga adalah semakin pendeknya hari rawat, sehingga jumlah klaim rumah sakit ke BPJS semakin rendah, sehingga berdampak bagi penurunan anggaran biaya perawatan masyarakat secara nasional. Produk Jasa Layanan Mutiara Home Care memiliki keunggulan dibandingkan home care lain. Pertama, Mutiara Home care akan dikelola dan diorganisir secara profesional oleh tenaga dosen profesional dibidang kesehatan dan keperawatan. Selama ini, home care dilakukan secara individu atau berkelompok tanpa wadah atau organisasi yang jelas. Tenaga kesehatan yang akan ditempatkan di komunitas atau di rumah telah terlatih dimulai sejak masa pendidikan dan tersertifikasi dari USM-Indonesia. Kedua, menyediakan layanan antar jemput pasien yang membutuhkan perawatan rumah sakit atau pemeriksaan khusus, seperti radiologi dan laboratorium. Layanan Mutiara Home Care pada tahap awal melayani pasien paska stroke dan perawatan lanjutan jantung, perawatan pasien DM dengan atau tanpa luka dan perawatan pasien lanjut usia. Secara bertahap akan dilakukan pengembangan serta layanan terhadap berbagai penyakit yang membutuhkan jasa perawatan profesional di rumah.
\end{abstract}

Kata Kunci: Home care, Mutiara

\begin{abstract}
The long-term goal of the Mutiara Home Care program is to create access to new entrepreneurs, to support college campus autonomy through the acquisition of independent income. For patients this program helps alleviate the cost of increasingly expensive hospitalization, as it reduces patient accommodation costs, transportation and family consumption. The national economic impact of home care for patients and families is the shortening of day care, so the number of hospital claims to BPJS is lower, thus impacting the reduction of national community maintenance budget. Products Care Services Pearl Home Care has advantages over other home care. First, Mutiara Home care will be managed and organized professionally by professional lecturers in the field of health and nursing. During this time, home care is done individually or in groups without a clear container or organization. Health workers who will be placed in the community or at home have been trained since the education and certified from USM-Indonesia. Secondly, it provides a shuttle service to patients who require hospital treatment or special examinations, such as radiology and laboratories. Pearl Home Care Services in the early stages of serving post-stroke patients and advanced heart care, treatment of DM patients with or without injuries and care of elderly patients. Gradually will be developed as well as services against various diseases that require professional care services at home.
\end{abstract}

Keywords: Homecare, Mutiara

\section{PENDAHULUAN}

Perkembangan ilmu dan teknologi saat ini, berdampak besar terhadap tuntutan masyarakat terhadap peningkatan layanan kesehatan. Pada masa lampau, masyarakat akan pergi ke fasilitas layanan kesehatan, seperti rumah sakit, klinik, praktek dokter dan layanan kesehatan lainnya jika membutuhkannya, akan tetapi saat ini, banyak masyarakat membutuhkan jasa layanan kesehatan di komunitas atau di rumah. Selain itu, sistem jaminan kesehatan saat ini dengan prinsip masa hari rawatan di rumah sakit sesingkat mungkin, sehingga banyak pasien atau masyarakat membutuhkan perawatan lanjutan di rumah, terutama pada kasus kasus paska stroke, diabetes dengan luka diabetik dan penyakit jantung. 
Saat ini, layanan layanan home care masih dominan dilakukan oleh individu tenaga kesehatan, khususnya perawat dan dokter keluarga dan belum terorganisasi secara baik, selain itu biasanya masyarakat yang membutuhkan tenaga kesehatan profesional untuk melakukan perawatan di rumah menghubungi rumah sakit agar bersedia mengirimkan perawat atau dokternya untuk visiting ke rumah. Hasil kajian Depkes RI tahun 2000, diperoleh hasil : 97,7 \% menyatakan perlu dikembangkan pelayanan kesehatan di rumah, 87,3\% mengatakan bahwa perlu standarisasi tenaga, sarana dan pelayanan, serta 91,9 $\%$ menyatakan pengelola keperawatan kesehatan di rumah memerlukan izin operasional.

Home care adalah pelayanan kesehatan yang berkesinambungan dan komprehensif yang diberikan kepada individu dan keluarga di tempat tinggal mereka yang bertujuan untuk meningkatkan, mempertahankan atau memulihkan kesehatan atau memaksimalkan tingkat kemandirian dan meminimalkan akibat dari penyakit (Depkes, 2012). Kebutuhan akan layanan home care sangatlah tinggi, hal ini seiring dengan peningkatan prevalensi penyakit kronis atau long life desease, seperti stroke, penyakit jantung dan diabetes melitus.

Berdasarkan hasil Riskedas tahun 2013 prevalensi pasien stroke Nasional 10,3\% dan Sumatera Utara 6 $\%$ dari total populasi, sementara prevalensi pasien penyakit jantung Nasional 6,7\% dan Sumatera Utara $6,6 \%$ dari total populasi dan prevalensi penyakit diabetes melitus Nasional 2,3\% dan Sumatera Utara $1,8 \%$. Sementara data di RSU Sari Mutiara Medan, tahun 2015 jumlah pasien stroke (124 orang) penyakit jantung (104 orang) dan DM (220 orang). Bulan Februari sampai dengan Mei 2016, jumlah penyakit stroke (64 orang), penyakit DM (119 orang), penyakit jantung (70 orang). Ketiga penyakit tersebut merupakan 10 penyakit terbesar di RSU Sari Mutiara Medan. Ketiga penyakit tersebut membutuhkan perawatan yang lama dan perlu perawatan lanjutan di komunitas atau di rumah dalam masa rehabilitasi dan proses pemulihan. Kondisi tersebut saat ini dan masa yang akan datang sangat membutuhkan jasa layanan kesehatan atau perawatan oleh tenaga profesional yang terorganisir secara baik dan profesional.

Kondisi pasien stroke ketika pulang dari rumah sakit, seringkali masih mengalami gejala sisa, misalnya gangguan motorik (hemiplegi/hemiparese) atau pasien yang pulang dengan keadaan bedrest total, kehilangan komunikasi atau kesulitan berbicara, gangguan persepsi, kerusakan fungsi kognitif dan efek psikologik akan berdampak pada aktivitas hidup sehari-hari, sehingga peran keluarga sangat dibutuhkan untuk merawat anggota keluarga pasca stroke (American Stroke Association, 2014; Mulyatsih, 2010).
Sementara hampir 50\% pasien dengan gagal jantung mengalami penurunan kualitas hidup karena ketidakmampuan secara fisik, sehingga sangat diperlukan adanya home care sebagai tindak lanjut dari perawatan di rumah sakit untuk menurunkan kejadian dirawat kembali, menurunkan cost dan meningkatkan kualitas hidup (Smeltzer, et al, 2008). Pasien DM dengan komplikasi luka, diperlukan teknik perawatan luka yang benar. Perawatan luka tidak bisa dilakukan sendiri oleh pasien atau keluarga, jika pasien memilih untuk tetap dilakukan rawat inap di rumah sakit sampai luka sembuh dibutuhkan waktu lama dan biaya yang besar, sehingga mutlak dibutuhkan perawat home care untuk perawatan luka (Howthorne, et al, 2010).

Berdasarkan pengamatan di lapangan, khususnya di kota Medan belum ada layanan home care yang diorganisasi secara profesional. Banyak rumah sakit di kota Medan, termasuk RSU Sari Mutiara yang belum menyediakan pelayanan home care bagi para pasiennya, membuat pendirian Mutiara home care menjadi prospek usaha yang cemerlang dan mampu berkembang diranah instansi kesehatan. Home care dilatarbelakangi, salah satunya, oleh permintaan keluarga penderita yang diharuskan opname, namun tempat di rawat inap penuh, sementara untuk ke RSU merasa keberatan dalam hal biaya. Berbagai manfaat yang didapatkan dalam layanan home care.

Pendirian unit kreativitas kampus yang bergerak dibidang jasa layanan kesehatan komunitas atau di rumah sangat memiliki peluang yang besar saat ini maupun masa yang akan datang. Mengingat Universitas Sari Mutiara Indonesia (USM-Indonesia) memiliki Program Studi Imu Keperawatan, Program Studi Ners, Program Studi DIII Kebidanan yang menghasilkan tenaga keperawatan dan kebidanan profesional dan siap bekerja di komunitas maupun di rumah. Pendirian Mutiara Home Care juga dapat memberikan peluang bagi mahasiswa prodi Ners, DIII Keperawatan untuk mengambil peminatan home care di komunitas.

Dampak sosial home care bagi pasien dan keluarga antara lain; 1) home care memberikan perasaan aman karena berada dilingkungan yang dikenal oleh klien dan keluarga, sedangkan bila di rumah sakit klien akan merasa asing dan perlu adaptasi; 2) home care merupakan satu cara dimana perawatan 24 jam dapat diberikan secara fokus pada satu klien, sedangkan dirumah sakit perawatan terbagi pada beberapa pasien; 3) home care memberi keyakinan akan mutu pelayanan keperawatan bagi klien, dimana pelayanan keperawatan dapat diberikan secara komprehensif (biopsikososiospiritual); 4) home care menjaga privacy klien dan keluarga, dimana semua tindakan yang berikan hanya keluarga dan tim kesehatan yang tahu; 5) home care memberikan kemudahan kepada keluarga dan care giver dalam memonitor kebiasaan klien seperti makan, minum, dan pola tidur dimana 
berguna memahami perubahan pola dan perawatan klien; 6) home care memberikan perasaan tenang dalam pikiran, dimana keluarga dapat melakukan kegiatan lain dengan tidak meninggalkan klien; 7) pelayanan home care lebih memastikan keberhasilan pendidikan kesehatan yang diberikan, perawat dapat memberi penguatan dalam pelaksanaan perawatan yang dilakukan keluarga.

Oleh karena itu perlu dikembangkan suatu wadah atau organisasi yang mampu menjawab tantangan tersebut, mampu menyediakan layanan kesehatan yang dilaksanakan oleh tenaga profesional di masyarakat atau di rumah. Kebutuhan akan kesinambungan asuhan keperawatan (continuity of care) dan integrasi home care sebagai komponen penting dalam sistem jaringan Rumah Sakit dengan Komunitas (Hospital - Based Home Care), melalui layanan home care, klien dengan kondisi pasca akut dan disable atau dengan kondisi penyakit kronis tidak lagi perlu menjalani hospitalisasi, sehingga pasien dan keluarga diberdayakan untuk turut ambil bagian dalam upaya proses pemulihan ataupun melakukan upaya prevensi sekunder dan tersier, bantuan yang diberikan oleh perawat home care sesuai dengan porsi dan kebutuhan.

Tujuan penulisan artikel adalah untuk menggambarkan pelaksanaan home care di Universitas Sari Mutiara Indonesia. Dampak ekonomi home care bagi keluarga dapat menghemat biaya konsumi dan akomodasi anggota keluarga, karena perawatan dilakukan di rumah. Dampak ekonomi nasional pelayanan home care adalah semakin pendeknya hari rawat, sehingga jumlah kalim rumah sakit ke BPJS semakin rendah, hal ini tentu berdampak bagi penurunan anggaran biaya perawatan masyarakat secara nasional.

\section{BAHAN DAN METODE}

Mutiara Home Care merupakan suatu usaha yang bergerak di bidang pelayanan kesehatan di komunitas atau di rumah. Mutiara Home care menerima pasien dari rumah sakit, puskesmas, sarana lain, keluarga. Secara khusus, home care ini melayani perawatan paripurna paska hospitalisasi. Mutiara Home Care tahap awal memfokuskan kepada pasien paska stroke, perawatan lanjut penyakit jantung dan penyakit DM. Kondisi pasien stroke ketika pulang dari rumah sakit, seringkali masih mengalami gejala sisa, misalnya gangguan motorik (hemiplegi/hemiparese) atau pasien yang pulang dengan keadaan bedrest total, kehilangan komunikasi atau kesulitan berbicara, gangguan persepsi, kerusakan fungsi kognitif dan efek psikologik akan berdampak pada aktivitas hidup sehari-hari, sehingga peran keluarga sangat dibutuhkan untuk merawat anggota keluarga pasca stroke (American Stroke Association, 2014; Mulyatsih, 2010).
Layanan Mutiara Home Care secara teknis memerlukan keterampilan dan pengetahuan para tim medisnya. Semua perawat yang akan direkrut untuk dilatih menjadi tenaga home care adalah perawat dan yang telah lulus uji kompetensi nasional yang ditunjukkan dengan surat keterangan lulus uji kompetensi dari institusi pendidikan dan lampiran print out pengumuman hasil uji kompetensi nasional, dengan demikian semua tenaga yang bekerja di Mutiara Home Care telah memiliki kompetensi dasar tenaga kesehatan.

Spesifikasi layanan Mutiara home care antara lain; 1) call centre; 2) layanan konseling dan pendidikan kesehatan seperti gizi, pengenalan faktor resiko, tindakan gawat darurat di rumah; 3) home visiting; 4) layanan perawatan 24 jam di rumah oleh perawat profesional; 5) layanan rehabilitasi dan pemulihan seperti latihan terapi wicara, fisioterapi latihan mobilisasi, perawatan luka diabetik; 6) Layanan antar jemput klien dengan mobil untuk rawat inap, pemeriksaan khusus diagnostik; 7) Pengambilan sampel laboratorium di rumah.

Selain itu pelaksanaannya didukung oleh alat dan bahan-bahan kesehatan (tensimeter, stetoskop, misalnya kapas, betadine, alkohol, gel, set pemeriksaan bahan laboratorium, set perawatan luka, set infus, sarung tangan, masker, mesin EKG, sterilisator kering dan lain-lain). Selain alat-alat kesehatan, dibutuhkan peralatan non kesehatan, seperti telepon kantor, telepon selular bagi perawat pelaksana, komputer, printer, meja, kursi, almari dan lain-lain.

Paska home care, pengelola mengirimkan kuesioner kepuasan pasien dan keluarga terkait kinerja perawat yang bekerja merawat anggota keluarga di rumah. Hasil kuesioner tersebut dijadikan umpan balik atau masukan terkait kinerja pelaksana home care, untuk dijadikan perbaikan dimasa yang akan datang.

\section{HASIL DAN PEMBAHASAN}

Dalam menyiapkan layanan home care oleh tenaga perawat yang profesional, maka Mutiara Home Care telah menetapkan beberapa aturan yang telah dituangkan dalam buku pedoman peraturan, termasuk angaran dasar dan anggaran rumah tangga organisasi, menyusun buku pedoman home care, aturan dan kode etik, pedoman pelatihan pengetahuan, ketrampilan dan komunikasi yang dilengkapi dengan standar kompetensi minimal menjadi tenaga di Mutiara Home Care. Syarat lain adalah semua perawat yang akan direkrut dilatih menjadi tenaga home care adalah perawat dan yang telah lulus uji kompetensi nasional yang ditunjukkan dengan surat keterangan lulus uji kompetensi dari institusi pendidikan dan lampiran print out pengumuman hasil uji kompetensi nasional, dengan demikian semua tenaga yang bekerja di Mutiara Home Care telah memiliki kompetensi dasar tenaga kesehatan. 
Selanjutnya dilakukan proses seleksi dan yang lulus seleksi diwajibkan mengikuti pelatihan dan workshop peningkatan pengetahuan, skill dan sikap/ komunikasi di komunitas dan keluarga. Proses pelatihan dan workshop mengacu pada buku pedoman dan standar kompetensi yang telah ditetapkan. Tenaga yang dinyatakan siap bekerja sebagai tenaga home care adalah yang telah lulus pelatihan dan workshop dan mencapai standar kompetensi. Pelatihan dan Workshop menjadi perawat home care telah dilaksanakan selama 5 hari pada tanggal 20-24 Maret 2017. Pelatihan dan workshop tersebut melibatkan mitra kerja yaitu tim expert RSU Sari Mutiara Medan, Psikolog USM-Indonesia dan Manajemen Mutiara Home Care (dosen) sesuai bidang keahlianya masing-masing. Peserta pelatihan sebanyak 10 orang perawat dan 1 orang ahli fisioterapi. Pelatih/narasumber : perawat spesialis kardiovaskuler, perawat spesialis neurologi, perawat terampil endokrin, ahli fisioterapi, dokter umum dan psikologi. Semua tenaga perawat yang akan ditugaskan merawat di komunitas atau di rumah wajib telah memiliki sertifikat perawat home care dari USM-Indonesia.

Perawat yang melakukan pelayanan keperawatan di rumah (home care) mempunyai peran untuk meningkatkan kemampuan keluarga untuk mencegah penyakit dan peme-liharaan kesehatan sehinga penerapan proses keperawatan di rumah, terjadi proses alih peran dari perawat kepada klien dan keluarga (sasaran), dan diharapkan secara bertahap dapat mencapai kemandirian klien beserta keluarga sasaran dalam menyelesaikan masalah kesehatannya.

Dalam hal menyiapkan jasa layanan home care oleh tenaga perawat yang profesional, maka Mutiara Home Care bekerja sesuai dengan Standar Operasional Procedur (SOP) seperti pemberian oksigen, perawatan luka, pemantauan hipertensi, pemberian latihan wicara, dan lain-lain. Mutiara Home Care juga menetapkan beberapa aturan yang telah dituangkan dalam buku pedoman home care, aturan dan kode etik, pedoman pelatihan pengetahuan, ketrampilan dan komunikasi.

Kegiatan-kegiatan promosi hingga saat ini masih tetap dilakukan, baik melalui berbagai kegiatan yaitu menyebarkan informasi keberadaan dan jenis layanan Mutiara Home Care melalui penyebaran leaflet dan poster ke rumah rumah sakit, puskesmas, klinikklinik. Selain penyebaran leaflet, penyebaran informasi juga dilakukan dengan memberdayakan ikatan alumni Program Studi Ilmu Keperawatan dan Program Studi Ners. Tujuan promosi adalah untuk memperkenalkan usaha homecare yang masih dapat dikatakan belum cukup dikenal oleh masyarakat, dikarenakan masyarakat masih menganggap universitas hanyalah sebagai tempat untuk mengenyam pendidikan bukan sebagai tempat untuk mengembangan suatu usaha.

Jumlah pasien homecare pada bulan april masih belum sesuai dengan target capaian karena awal pembukaan dan masih dalam promosi. Kunjungan rumah pada bulan April sampai dengan Juli tahun 2017 adalah : Bulan April 2017 (32 orang), terdiri stroke $=9$ orang, Hipertensi/Jantung $=7$ orang dan Endokrin/DM = 16 orang. Bulan Mei 2017 (40 orang), terdiri dari stroke $=9$ orang, hipertensi/Jantung $=12$ orang dan endokrin/DM $=19$ orang, Bulan Juni 2017 (51 orang) terdiri dari stroke $=15$ orang, hipertensi/Jantung $=16$ orang dan endokrin/DM $=20$ orang. Bulan Juli 2017 (65 orang), terdiri dari stroke $=18$, hipertensi $/$ Jantung $=$ 17 orang dan endokrin/DM $=30$ orang.

Kebutuhan akan kesinambungan asuhan keperawatan dengan integrasi home care sebagai komponen penting dalam sistem jaringan rumah sakit dengan komunitas. Melalui layanan home care, klien dengan kondisi pasca akut dan disable atau dengan kondisi penyakit kronis tidak lagi perlu menjalani hospitalisasi sehingga pasien dan keluarga diberdayakan untuk turut ambil bagian dalam upaya proses pemulihan ataupun melakukan upaya prevensi sekunder dan tersier, bantuan yang diberikan oleh perawat home care sesuai dengan porsi dan kebutuhan.

Home care merupakan bagian atau lanjutan dari pelayanan kesehatan yang berkesinambungan dan komprehensif yang diberikan kepada individu dan keluarga di tempat tinggal mereka yang bertujuan untuk meningkatkan, mempertahankan atau memulihkan kesehatan atau memaksimalkan tingkat kemandirian dan meminimalkan dampak penyakit. Pelayanan home care juga meliputi konseling yang bermanfaat meningkatkan kepatuhan pasien dalam penggunaan obat, sehingga angka kematian dan kerugian (baik biaya maupun hilangnya produktivitas) dapat ditekan (Schnipper, 2006).

Hasil kuisioner kepuasan pasien menyatakan bahwa sebagian besar $(90 \%)$ menyatakan kepuasan terhadap kinerja perawat yang bekerja merawat anggota keluarga di rumah. Hal ini menunjukkan bahwa kepuasan pasien tidak hanya dari segi pemberian pendidikan kesehatan saja namun juga dipengaruhi oleh beberapa hal diantaranya faktor kenyamanan dengan perawat, hubungan pasien dengan petugas RS dan biaya (Mulyanasari, 2014). Perawat yang melakukan pelayanan keperawatan di rumah (home care) mempunyai peran untuk meningkatkan kemampuan keluarga untuk mencegah penyakit dan pemeliharaan kesehatan sehinga penerapan proses keperawatan di rumah, terjadi proses alih peran dari perawat kepada klien dan keluarga (sasaran), dan diharapkan secara bertahap dapat mencapai kemandirian klien beserta keluarga sasaran dalam 
menyelesaikan masalah kesehatannya (Depkes, 2006).

Layanan home care memiliki luaran dalam bentuk penelitian dengan topik Pengaruh Pemanfaatan Homecare dengan Kepatuhan Pasien DM. Kuisioner telah dibagikan kepada pasien homecare dengan diagnosa medis DM. Luaran lainnya adalah membuat buku ajar terkait homecare pada pasien DM, hipertensi dan paska stroke.

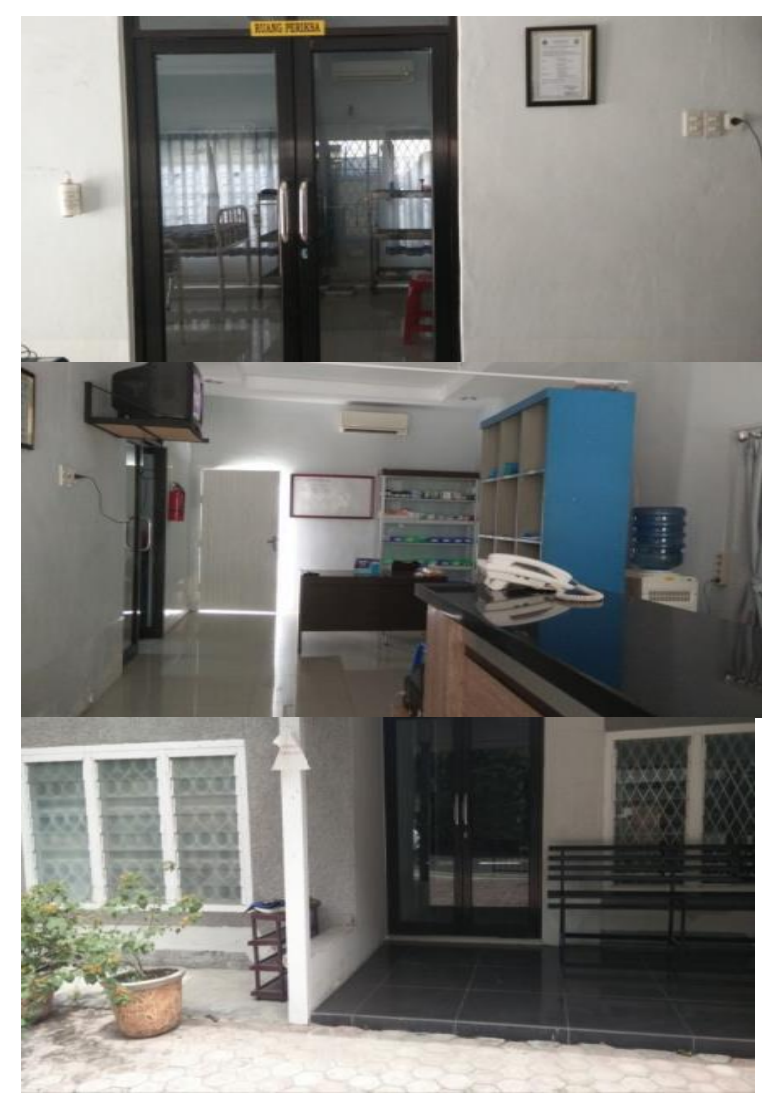

\section{Gambar 1.1 Mutiara Home Care}

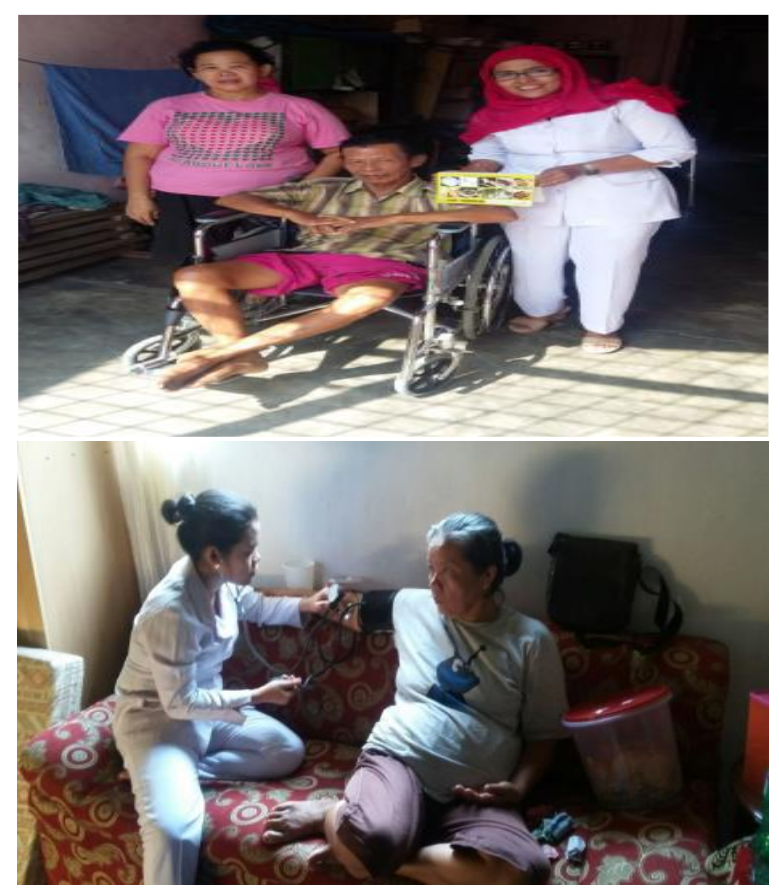

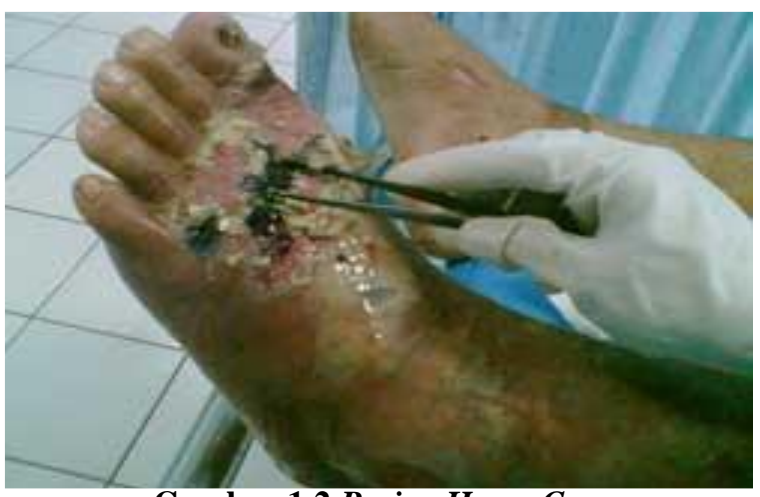

Gambar 1.2 Pasien Home Care

\section{KESIMPULAN}

Tanggapan yang positif dari masyarakat pengguna pelayanan home care karena perawat memiliki pengetahuan, keterampilan dan sikap yang sesuai dengan kebutuhan stake holder serta melakukan pelayanan secara komprehensif.

\section{UCAPAN TERIMA KASIH}

Penulis mengucapkan terima kasih sebesar-besarnya kepada Direktur Pengabdian Masyarakat Kementerian Riset dan Teknologi Pendidikan Tinggi atas hibah yang telah diberikan. Juga kepada Universitas Sari Mutiara Indonesia dan Rumah Sakit Umum Sari Mutiara yang telah memberikan dukungan, fasilitas dan sarana prasarana selama melaksanakan mutiara home care.

\section{DAFTAR PUSTAKA}

Benack R.T. (2008). Congestive Heart Failure the Patient and the Community, Conference Arlington. USA.

Betty A. L., Ellen M., Tang M.J. H. (2006). Home Monitoring of Congestive Heart Failure Patients Proceedings of the 1st Distributed Diagnosis and Home Healthcare. Conference Arlington. Virginia. USA.

Hawthorne, K., Robles, Y., Cannings-John R., \& Edwards, AG (2010). Culturally appropriate health education for Type 2 diabetes in ethnic minority groups: a systematic and narrative review of randomized controlled trials. Diabetes Med. 2010 Jun; 27(6): 613-23. Diakses melalui http://www.ncbi.nlm.nih.gov/pubmed/205462 77 pada tanggal 20 Mei 2016.

Kementerian Kesehatan Republik Indonesia. (2013). Riset Kesehatan Dasar Nasional. Jakarta. 
Mulyatsih E \& Ahmad A (2010). Stroke; Petunjuk Perawatan Pasien Pasca Stroke di Rumah. Jakarta: FK Universitas Indonesia.

Mulyanasari, F., Subekti, H., \& Kep, S. (2014). Evaluasi Pelaksanaan Pendidikan Pasien dan Keluarga Pada Pelayanan Home Care Berstandar Joint Commission International Di Rumah Sakit Panti Rapih Yogyakarta (Doctoral Dissertation, Universitas Gadjah Mada). (Diunduh pada tanggal 7 Agustus 2016). Diakses melalui http://etd.repository.ugm. ac.id/index.php?

Ostwald, S.K., Hearsch, G., Kelley, C., \& Godwin, K.M. (2008). Evidence-Based Educational Guidelines for Stroke Survivors After Discharge Home. Journal Neurosci Nurs, 40 (1), 173-191. Diakses melalui http://www.ncbi.nlm.nih.gov/ pmc/articles/PMC2743441/pdf/nihms107369.pdf. Diakses tanggal 28 April 2016.

Sawo, D., \& Cherofsky, N. (2005). Telehealth in adult patients with congestive heart failure in long term home health care: A systematic review.

Schnipper, 2006, Role of Pharmacist Counseling in Preventing Adverse Drug Events After Hospitalization,Arch. Intern. Med, 166:565571.

Smeletzer, S., et al. (2008). Brunner \& Suddarth Texbook of medical-surgical nursing, 11 th.ed. Lippincott William \& Wilkins. 